\title{
Axotomy-Induced Changes in the Expression of a Type III Neuronal Intermediate Filament Gene
}

\author{
Monica M. Oblinger, ${ }^{1}$ Johnson Wong, and Linda M. Parysek ${ }^{2}$ \\ 'Department of Cell Biology and Anatomy, Chicago Medical School, North Chicago, Illinois 60064 and ${ }^{2}$ Department of \\ Anatomy and Cell Biology, University of Cincinnati Medical School, Cincinnati, Ohio 45267
}

The effect of axotomy on the expression of the $57 \mathrm{kDa}$ neuronal intermediate filament (IF) protein in adult rat dorsal root ganglion (DRG) neurons was examined. This IF protein is known to have an exclusively neuronal localization but is considerably more limited in its distribution in the nervous system than the neurofilament (NF) triplet proteins. The $\mathbf{5 7}$ $\mathrm{kDa}$ neuronal IF protein is similar (and perhaps identical) to the protein "peripherin" and Is known to be the product of a Type III IF gene. Since the down-regulated expression of NF proteins (products of type IV IF genes) has been well established, it was of interest to determine whether the novel $57 \mathrm{kDa}$ IF protein was regulated in a similar or different manner from that of the NFs in axotomized neurons. In vitro pulse-labeling of DRGs with ${ }^{36} \mathrm{~S}$-methionine : cysteine followed by 2-dimensional gel electrophoresis/fluorography revealed that the synthesis of the $\mathbf{5 7} \mathrm{kDa}$ neuronal IF protein was increased 2 weeks after sciatic nerve crush. Immunocytochemical studies using a polyclonal antibody to the 57 kDa neuronal IF protein showed that the immunodetectable levels of this protein increased in DRG neurons after peripheral axotomy. In the normal DRG, staining was localized almost exclusively to small-sized neurons. At 2 weeks after axotomy, however, large- and medium-sized neurons also became immunoreactive; in addition, the overall level of staining in the DRG was greater than normal. Quantitative analysis of in situ hybridizations of DRG neurons with a ${ }^{35} \mathrm{~S}-$ labeled cDNA probe specific for the $57 \mathrm{kDa}$ neuronal IF protein revealed a significant increase in the level of $57 \mathrm{kDa}$ IF mRNA in the large-sized $\left(>1000 \mu \mathrm{m}^{2}\right)$ neurons 2 weeks after axotomy; the level of $57 \mathrm{kDa}$ IF mRNA in the small neurons was not different from normal at that time. Finally, using a newly developed paradigm for examining the composition of regenerating axons by axonal transport, we determined that significant amounts of the $\mathbf{5 7} \mathrm{kDa}$ neuronal IF protein were conveyed into the regrowing axonal sprouts of DRG neurons. When DRG neurons were conditioned by a previous axotomy (a crush axotomy of the distal sciatic nerve 2 weeks earlier) and then stimulated to regenerate axons by a second crush axotomy located very close to the DRG, the regener-

\footnotetext{
Received Apr. 10, 1989; revised May 26, 1989; accepted June 1, 1989.

We gratefully acknowledge the excellent technical assistance of Ben Sanchez in these studies and thank Dan Collins for his help in the immunocytochemistry studies. This work was supported by NIH grant NS-21571 to M.M.O.

Correspondence should be addressed to Dr. Monica M. Oblinger, Department of Cell Biology and Anatomy, Chicago Medical School, 3333 Green Bay Road, North Chicago, IL 60064.

Copyright (c) 1989 Society for Neuroscience $0270-6474 / 89 / 113766-10 \$ 02.00 / 0$
}

ating sprouts incorporated and conveyed significantly more $57 \mathrm{kDa}$ IF protein by slow axonal transport than did those elaborated by unprimed DRG neurons. These findings of upregulated expression of the $57 \mathrm{kDa}$ neuronal IF protein in axotomized DRG cells indicate that the expression of the Type III and IV neuronal IF genes is differentially regulated in response to axotomy.

The family of intermediate filament (IF) proteins is classified into 5 types based on analysis of sequence data (Steinert and Roop, 1988). Type I and II IFs include the acidic and basic keratins; type III IFs include vimentin, desmin, and glial fibrillary acidic protein; type IV IFs include the NF triplet proteins (NF-L, $68 \mathrm{kDa}$; NF-M, $145 \mathrm{kDa}$; NF-H, $200 \mathrm{kDa}$ ), and Type V IFs include the nuclear lamins. The majority of mammalian neurons express the NF triplet proteins (Shaw et al., 1981; Trojanowski ct al., 1986). In addition, a subsct of mammalian neurons has been shown to express a $57 \mathrm{kDa}$ IF protein (Portier et al., 1984b; Parysek and Goldman, 1988; Parysek et al., 1988; Brody et al., 1989), which is the major component of the cytoskeleton in PC12 cells (Portier et al., 1984a; Parysek and Goldman, 1987). Based on immunocytochemistry as well as in situ hybridization, the $57 \mathrm{kDa}$ neuronal IF protein or its mRNA has been shown to be present in some PNS components, including small neurons of the DRG, sympathetic ganglia, most cranial nerves, and ventral motor neurons (Portier et al., 1984b; Leonard et al., 1988; Parysek and Goldman, 1988; Brody et al., 1989). In addition, a number of nuclear groups in the adult rat CNS have also been shown to express the $57 \mathrm{kDa}$ neuronal IF protein (Leonard et al., 1988, Parysek and Goldman, 1988; Brody et al., 1989). The predicted amino acid sequence of the $57 \mathrm{kDa}$ IF protein, which may be identical to peripherin (Aletta et al., 1988), indicates that it is a type III IF protein (Leonard et al., 1988; Parysek et al., 1988; Thompson and Ziff, 1989). Thus, the currently characterized IFs that are expressed exclusively in neurons are encoded by both type III and IV IF genes.

The presence of this type III IF mRNA and its encoded 57 $\mathrm{kDa}$ protein in the nervous system raises many questions about the function of this protein. The observation that it is primarily (but not exclusively) distributed in neurons that have smallcaliber, unmyelinated axons suggests that it may have a function different from that of the NF triplet proteins. NFs are predominant in neurons with large myelinated axons, wherein they play an essential role in defining axonal caliber (Lasek et al., 1983; Hoffman et al., 1987). It is likely that progress towards understanding the possible function(s) of the $57 \mathrm{kDa}$ IF in the nervous system can result from studies of its expression during neuronal development and regeneration. Disconnection of the axon from 
its ncuronal cell body is well known to have a significant cffect on the expression of NFs. In adult DRG neurons, the expression of the NF (Type IV IF) genes is down-regulated after peripheral axotomy (Hoffman et al., 1987; Wong and Oblinger, 1987; Goldstein et al., 1988; Oblinger et al., 1989). In addition to changes in NF mRNA levels, axotomy results in down-regulated levels of NF protein synthesis and axonal transport in DRG neurons (Oblinger and Lasek, 1985, 1988; Greenberg and Lasek, 1988, Oblinger et al., 1989). The following question arises: is the novel $57 \mathrm{kDa}$ IF protein regulated in a similar or different manner from that of the NFs in axotomized DRG neurons?

In this study, we examined the effect of axotomy on the expression of the $57 \mathrm{kDa}$ neuronal IF protein using the wellcharacterized system of L5 DRG neurons of adult rats after unilateral sciatic nerve crush. We report the results from protein synthesis studies, immunocytochemical studies, in situ hybridization experiments and axonal transport studies, all of which indicate that the $57 \mathrm{kDa}$ IF gene is regulated differently than the NF genes during axonal regeneration. Our findings of up-regulated expression of the $57 \mathrm{kDa}$ neuronal IF protein in axotomized DRG neurons suggest that this protein has an essential function during axonal regrowth.

\section{Materials and Methods}

Animals. Adult male Sprague-Dawley rats (Harlan Sprague Dawley, Indianapolis, IN) weighing 300-350 gm were used for all experiments. All animals were acquired, cared for, and surgically handled in accordance with the guidelines specified in the NIH Guide for the Care and Use of Laboratory Animals. For surgical procedures, animals were anesthetized with a mixture of sodium pentobarbital $(27 \mathrm{mg} / \mathrm{kg})$ and chloral hydrate $(128 \mathrm{mg} / \mathrm{kg})$; for scheduled kills, animals were decapitated under ether anesthesia.

Protein synthesis studies. For in vitro labeling of newly synthesized DRG proteins, experimental and contralateral control L5 DRGs were removed from 4 rats $14 \mathrm{~d}$ after unilateral peripheral axotomy. For the axotomy, the distal sciatic nerve was crushed 3 consecutive times for $30 \mathrm{sec}$ with \#5 Dumont forceps at a distance of 50-60 mm from the L5 DRG. After removal from the animal, the ganglia were quickly desheathed, the ventral roots were dissected away from the bottom of the DRG, and the dorsal roots and peripheral nerves were trimmed very close to the ganglia. Each DRG was placed into $500 \mu \mathrm{l}$ of a methionineand cysteine-free MEM (Minimal Essential Media) solution made using a Select-Amine Kit (Gibco, Grand Island, NY). The DRGs were allowed to equilibrate at $37^{\circ} \mathrm{C}$ for $15 \mathrm{~min}$ with bubbling $95 \%$ oxygen and then transferred to $500 \mu \mathrm{l}$ of fresh MEM solution containing $500 \mu \mathrm{Ci}$ of ${ }^{35} \mathrm{~S}$ trans-label ( ${ }^{35} \mathrm{~S}$-methionine : cysteine; ICN Radiochemicals, Irvine, CA) for $1 \mathrm{hr}$ at $37^{\circ} \mathrm{C}$ with $95 \%$ oxygen bubbling. After labeling, the ganglia were homogenized in extraction buffer and the proteins separated into Triton X-100 insoluble (cytoskeletal fraction) and detergent-soluble fractions as described previously (Oblinger, 1987). The fractions were mixed with SUB $(0.5 \%$ SDS, $8 \mathrm{~m}$ urea, $2 \%$ beta-mercaptoethanol) and then subjected to isoelectric focusing followed by SDS-PAGE (2D gels) and fluorography as described previously (Oblinger, 1987).

Immunocytochemistry. Experimental and contralateral control L5 DRGs were removed from rats $14 \mathrm{~d}$ after unilateral distal sciatic nerve crush (50-60 mm from the ganglia). The DRGs were placed into $4 \%$ paraformaldehyde for $2 \mathrm{hr}$, dehydrated, and embedded in paraffin. The blocks were sectioned at $10 \mu \mathrm{m}$ and the histological sections mounted on gelatin-chrome alum-subbed slides. Slides were stored in covered slide boxes at room temperature until used for immunostaining. For staining, the sections were deparaffinized and then incubated in $4 \%$ normal goat serum (NGS) at room temperature for $1 \mathrm{hr}$. This blocking serum was lightly suctioned off, and primary antiscra (rabbit polyclonal antibody to the $57 \mathrm{~K}$ protein; Parysek and Goldman, 1987) was applied (1:1000 dilution in PBS containing $1 \%$ NGS) for $12-16 \mathrm{hr}$ at room temperature. The sections were rinsed with PBS and reacted with biotinylated anti-rabbit IgG (1:200 in PBS) for $1 \mathrm{hr}$. The sections were next incubated for $1 \mathrm{hr}$ with Vectastain Elite ABC Reagent (avidin DH/ biotinylated HRP $\mathrm{H}$; 1:50 with PBS; supplied as a kit from Vector Immunocytochemicals) and the reaction product visualized with $0.05 \%$ diaminobenzidine and $0.02 \%$ hydrogen peroxide. Nonimmune control sections were treated as described, except that primary antibody was omitted. After staining, slides were dehydrated, coverslipped with Permount, and examined by light microscopy.

In situ hybridization. The sciatic nerves of 6 adult rats were crushed unilaterally 50-60 mm from the L5 DRG. The axotomized L5 ganglia were removed 2 weeks after the nerve crush and fixed by immersion in $4 \%$ paraformaldehyde for $2 \mathrm{hr}$. Four untreated rats provided normal control L5 ganglia. The DRGs were embedded in paraffin, sectioned at $10 \mu \mathrm{m}$, and hybridized in situ with a ${ }^{35} \mathrm{~S}$-labeled $\mathrm{cDNA}$ as described previously (Wong and Oblinger, 1987), except that sections were washed to a final stringency of $0.5 \times$ SSC with $0.1 \%$ heta-mercaptoethanol at $45^{\circ} \mathrm{C}$ for $30 \mathrm{~min}$. The probe used for hybridization was a cDNA specific for the $57 \mathrm{kDa}$ IF protein (Parysek et al., 1988).

After hybridization, the sections were dehydrated through an increasing series of ethanol/300 $\mathrm{mm}$ ammonium acetate, dried, dipped into $37^{\circ} \mathrm{C}$ Kodak NTB2 emulsion (diluted $1: 1$ with $600 \mathrm{~mm}$ ammonium acetate) and stored at $4^{\circ} \mathrm{C}$ in the dark. Slides were developed after $8 \mathrm{~d}$ exposure and lightly counterstained with cresyl violet. The density of silver grains over DRG neurons in which clearly defined nucleus and nucleolus were present was determined using a computer-based imageanalysis system as described previously (Wong and Oblinger, 1987). Measurements of nonspecific background labeling were made from each section by determining the grain density over axonal regions of the DRG (that did not contain neuronal cell bodies); the grain counts over neurons from any given section were corrected for nonspecific labeling. Two size categories of neurons were examined: large neurons $\left(>1000 \mu \mathrm{m}^{2}\right)$ and small neurons $\left(<600 \mu \mathrm{m}^{2}\right)$. In each size category, $25-50$ neurons per ganglion were counted. To establish statistical significance between the normal and experimental material, an unpaired, 2-tailed Student's $t$ test at the $95 \%$ confidence level was used.

Axonal transport experiments. In order to label proteins conveyed by newly regenerating axons, the L5 DRG and a $6 \mathrm{~mm}$ stretch of the peripheral L5 nerve were exposed unilaterally and $2 \mu \mathrm{l}$ of saline containing $1 \mathrm{mCi}$ of ${ }^{s} \mathrm{~S}$-methionine (New England Nuclear) were microinjected into the midpoint of the DRG over a period of $10 \mathrm{~min}$. The DRG was flushed with saline, and immediately thereafter the L5 peripheral nerve was crushed $2-4 \mathrm{~mm}$ from the ganglion (test crush). Four normal rats were prepared in this manner and formed the "unprimed" condition. One group of 5 rats was used for the "primed" condition. In the latter group, a conditioning or priming lesion which consisted of a crush of the distal sciatic nerve (50-60 mm from the L5 DRG) was made 2 weeks prior to the labeling/test crush procedure. All animals were killed $7 \mathrm{~d}$ following labeling/test crush and the L5 DRGs and sciatic nerves were removed and frozen on dry ice. The DRG, the segment of nerve located proximal to the crush site $(2-4 \mathrm{~mm})$, and consecutive $10 \mathrm{~mm}$ segments of nerve located distal to the crush site (and which contained the newly regenerating axons) were dissected and homogenized in SUB. An aliquot of each sample was used to determine the total acid-precipitable radioactivity; the remaining sample was subjected to $2 \mathrm{D}$ gels/ fluorography. To verify the identity of the $57 \mathrm{kDa}$ protein, immunoblots of $2 \mathrm{D}$ gels were done as described previously (Oblinger, 1987) using a polyclonal antibody to the $57 \mathrm{kDa}$ IF protein (Parysek and Goldman, 1987).

\section{Results}

Synthesis of the $57 \mathrm{kDa} I F$ protein in axotomized $D R G$ cells

To examine whether axotomy affected the synthesis of the 57 $\mathrm{kDa}$ neuronal IF protein in adult DRG neurons, matched pairs of experimental and contralateral control L5 ganglia were harvested 2 weeks after distal sciatic nerve crush and pulse-labeled with ${ }^{35} \mathrm{~S}-$ methionine : cysteine in vitro for $1 \mathrm{hr}$. Since the $57 \mathrm{kDa}$ protein is a fairly minor labeled protein in gels of total DRG protein synthesis, proteins were first separated into cytoskeletal and soluble fractions using standard detergent (Triton X-100) extraction. The fluorographs of 2D gels of detergent-insoluble protein pellets revealed that the incorporation of label into the $57 \mathrm{kDa}$ IF protein was substantially greater in axotomized DRGs than in contralateral control ganglia (Fig. 1). This finding was consistently observed in 4 separate experiments and suggested that the synthesis of $57 \mathrm{kDa}$ was increased in DRG neurons 14 

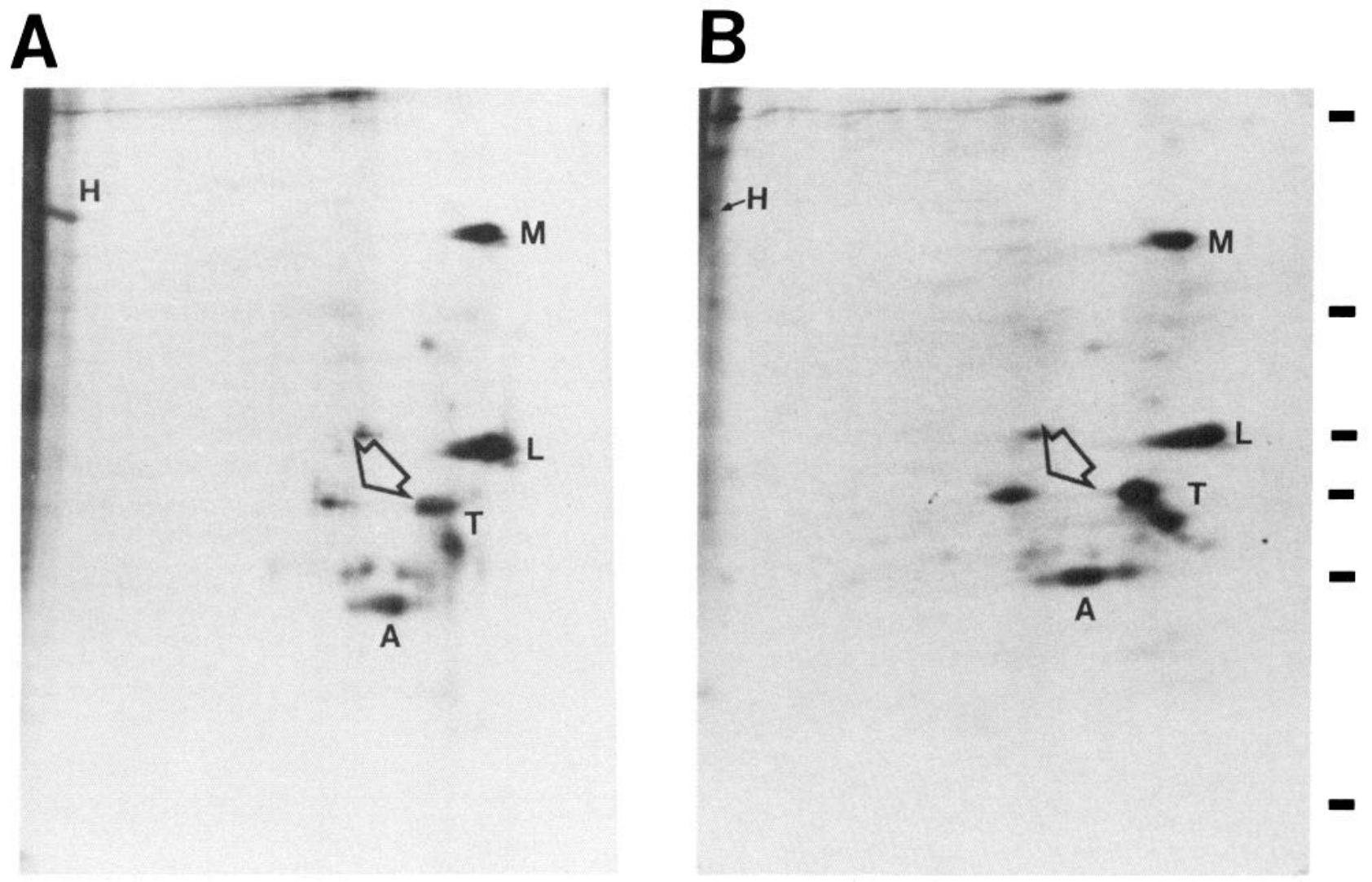

Figure 1. Fluorographs of 2D gels illustrating newly synthesized cytoskeletal proteins in $(A)$ contralateral control DRGs and $(B)$ axotomized DRGs $14 \mathrm{~d}$ after distal sciatic nerve crush. Proteins were labeled by incubating DRGs in ${ }^{35} \mathrm{~S}-$ methionine: cysteine for $1 \mathrm{hr}$ in vitro. The DRGs were detergent-extracted (Triton X-100) after labeling as described in Materials and Methods and the detergent-insoluble (cytoskeletal) protein fraction was used for the 2D gels. The open arrows indicate the $57 \mathrm{kDa}$ IF protein; $T$ designates the tubulins, $A$ designates the position of actin; $L, M$, and $H$ mark the position of the NF triplet proteins. Molecular-weight standards indicated on the far-right side of gel panels depict 200, 97, 68, 57, 43, and $14 \mathrm{kDa}$.

$\mathrm{d}$ after axotomy. The fluorographs also revealed that by $1 \mathrm{hr}$ after labeling, the $57 \mathrm{kDa}$ IF protein quantitatively partitioned with the detergent-insoluble (cytoskeletal) pellet. No label in the position of the $57 \mathrm{kDa}$ IF protein was found in $2 \mathrm{D}$ gels of the soluble protein fraction from $1 \mathrm{hr}$ pulse-labeling experiments (Fig. 2). This indicated that the $57 \mathrm{kDa}$ IF protein was assembled into the cytoskeleton within $1 \mathrm{hr}$ of synthesis.

\section{Immunocytochemical studies of $57 \mathrm{kDa} I F$ protein in axotomized DRG neurons}

The level of immunodetectable $57 \mathrm{kDa}$ IF protein in axotomized versus contralateral control DRG neurons was examined using immunocytochemistry. In control ganglia, the $57 \mathrm{kDa}$ IF protein was found almost exclusively in the small sensory neurons (Fig. $3, A, C)$. In contrast, $14 \mathrm{~d}$ after distal sciatic nerve crush, immunodetectable $57 \mathrm{kDa}$ IF protein was present in many of the larger DRG neurons, as well as in the small DRG neurons (Fig. $3, B, D$ ). In control sections where primary antibody was omitted from the immunohistochemical procedure, DRG cell bodies and axons were not stained (not shown). Sections of paired L5 DRGs (14 d postaxotomy and matched contralateral controls) from 8 different animals that were immunostained together were scored. The following observations were consistent in all pairs. First, the overall number of immunoreactive neurons appeared to be greater in axotomized than in control DRGs (Fig. 3, $A$, $B)$. Second, immunostaining was frequently observed in large- and medium-sized neurons in axotomized preparations but rarely in control preparations (Fig. 3, $C, D$ ). Third, the intensity of immunostaining of the small-sized neurons in the $14 \mathrm{~d}$ postaxotomy DRGs was substantially greater than that in paired control DRGs. In many cases, the heaviest staining was in cablelike structures located around the eccentric nucleus of chromatolytic neurons (Fig. 3D). These findings indicated that the somal content of immunodetectable $57 \mathrm{kDa}$ IF protein was substantially increased in both small and large DRG neurons at $14 \mathrm{~d}$ postaxotomy. In addition to the differences in somal staining, it was also apparent that the level of axonal staining with the $57 \mathrm{kDa}$ antibody was greater in the axotomized preparations than in control ganglia (Fig. 3, $A, B$ ).

\section{In situ hybridization of axotomized DRG neurons with a cDNA to the $57 \mathrm{kDa}$ IF $\mathrm{mRNA}$}

To examine the level of mRNA for the $57 \mathrm{kDa}$ IF protein after axotomy and to determine if all sizes of neurons in the DRG exhibited a change in $57 \mathrm{kDa}$ IF transcript levels, in situ hybridizations of histological sections of L5 DRGs were done using a labeled cDNA specific for the $57 \mathrm{kDa}$ IF protein mRNA. The autoradiograms of normal DRG neurons hybridized with the ${ }^{35} \mathrm{~S}$-labeled cDNA probe revealed the presence of the $57 \mathrm{kDa}$ IF mRNA in both small- $\left(<600 \mu \mathrm{m}^{2}\right)$ and large-sized $(>1000$ $\left.\mu \mathrm{m}^{2}\right)$ DRG neurons; however, the density of silver grains was quantitatively higher over small neurons than over large neurons 
INSOLUBLE

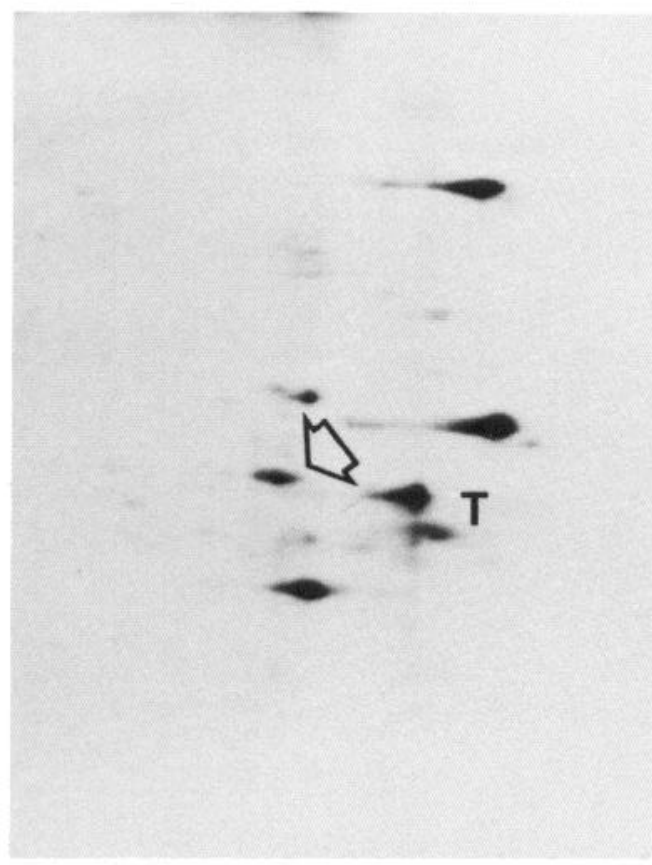

SOLUBLE

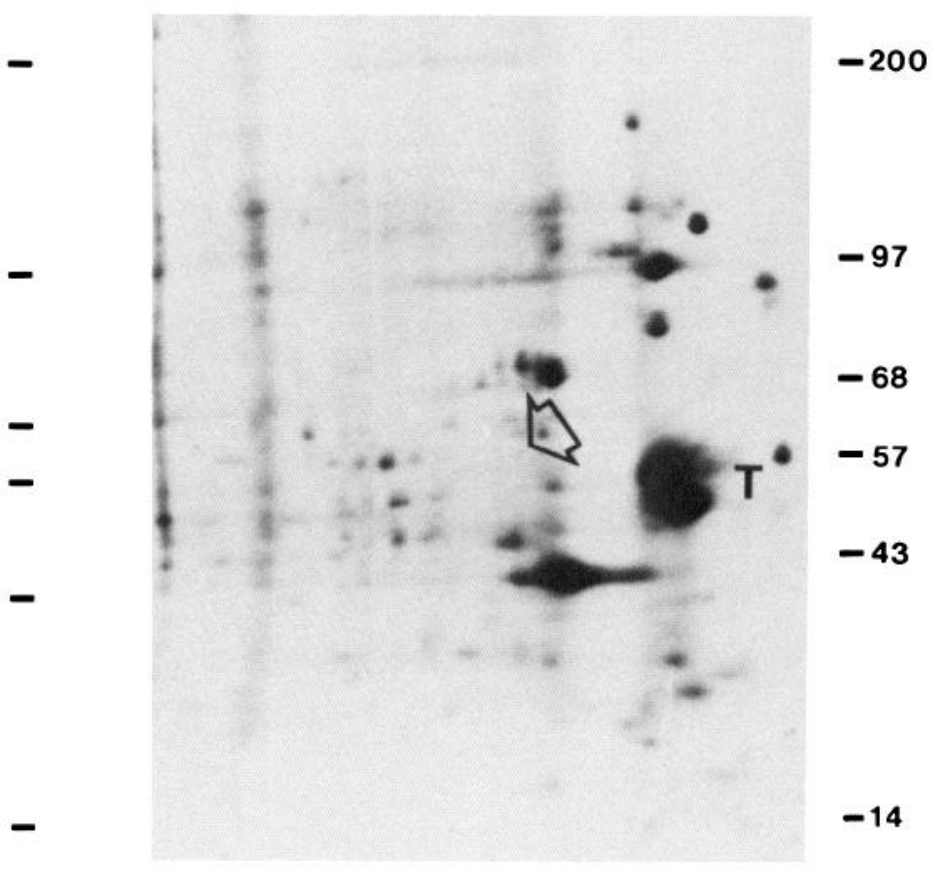

Figure 2. Fluorographs of detergent-insoluble and detergent-soluble proteins from a normal DRG labeled in vitro with ${ }^{35} \mathrm{~S}$-methionine : cysteine for $1 \mathrm{hr}$. Labeled DRGs were extracted with Triton X-100 as described in Materials and Methods. Note that the $57 \mathrm{kDa}$ protein (open arrows) is found only in the detergent-insoluble (cytoskeletal) pellet. $T$ marks the position of the $\alpha$-and $\beta$-tubulins. Molecular-weight standards are indicated on the far-right side of gel panel in kilodaltons.

(Figs. 4, 5). Comparisons of autoradiograms of DRG neurons that had sustained a distal sciatic nerve crush $14 \mathrm{~d}$ earlier with those of normal control DRG neurons indicated that the level of $57 \mathrm{kDa}$ IF mRNA was increased in the large-sized DRG cells after axotomy (Fig. 4). Quantitation of grain densities over the large-sized DRG neurons confirmed the qualitative observations. The mean grain density over large DRG neurons at 2 weeks after axotomy was significantly higher $(p<0.05)$ than that over large normal control DRG neurons (Fig. 5). In contrast to the large neurons, the level of $57 \mathrm{kDa}$ IF mRNA in the smallsized DRG cells in axotomized preparations was not significantly different from that in normal controls (Fig. 5).

\section{Transport of $57 \mathrm{kDa}$ neuronal IF protein in regenerating axonal sprouts of primed vs unprimed DRG neurons}

Axonal transport of the $57 \mathrm{kDa}$ IF protein in regenerating axonal sprouts of DRG neurons was examined by SDS-PAGE/fluorography. Proteins synthesized by primed and unprimed L5 DRG neurons were radiolabeled by microinjection of ${ }^{35} \mathrm{~S}$-methionine into the ganglion and, immediately thereafter, the peripheral L5 nerve was crushed at a distance of $2-4 \mathrm{~mm}$ from the L5 ganglion (test crush site). In this paradigm, new axonal sprouts elaborated by DRG neurons in response to the test crush grew distally from the parent stump of axon and incorporated radiolabeled proteins synthesized by the L5 DRG neurons as they elongated. In the "unprimed" condition, protein synthesis was labeled in normal, uninjured DRG neurons. In the "primed" condition, a crush of the distal sciatic nerve was made 2 weeks prior to the labeling/test crush procedure. Thus, in the primed condition, protein synthesis was labeled in $14 \mathrm{~d}$ postaxotomy neurons. In both conditions, the test crush immediately followed the protein labeling and the regenerating axonal sprouts were harvested $7 \mathrm{~d}$ later. The temporal parameters of the experiment targeted the cytoskeletal proteins which are conveyed by slow axonal transport.

Fluorographs illustrated major differences in the amount of $57 \mathrm{kDa}$ neuronal IF protein that entered regenerating sprouts of unprimed and primed DRG neurons by slow axonal transport (Fig. 6). The amount of radiolabeled $57 \mathrm{kDa}$ IF protein clearly was greater in the sprouts of primed DRG neurons compared to unprimed neurons (Fig. 6). This finding consistently was made in 6 separate experiments. In contrast to the $57 \mathrm{kDa}$ IF protein, regenerating axonal sprouts of primed DRG cells incorporated and conveyed significantly less labeled NF protein than did those of unprimed DRG neurons (Fig. 6; see also Oblinger et al., 1989). The difference in the content of $57 \mathrm{kDa}$ IF protein in regenerating sprouts of primed and unprimed neurons also was seen on $2 \mathrm{D}$ gel immunoblots using a polyclonal antibody (Fig. 7). The amount of immunoreactive $57 \mathrm{kDa}$ protein obtained from regenerating nerve segments from primed systems clearly was greater than that obtained from unprimed systems (Fig. 7). This observation was confirmed in 3 separate experiments. These findings suggested that increased amounts of the $57 \mathrm{kDa}$ neuronal IF protein were axonally transported in regenerating axonal sprouts of conditioned or primed DRG neurons compared with unprimed neurons.

\section{Discussion}

Type III and Type IV neuronal IFs are differentially regulated in adult neurons

Adult neurons express proteins that are products of type III and type IV IF genes. The vast majority of neurons in the nervous 

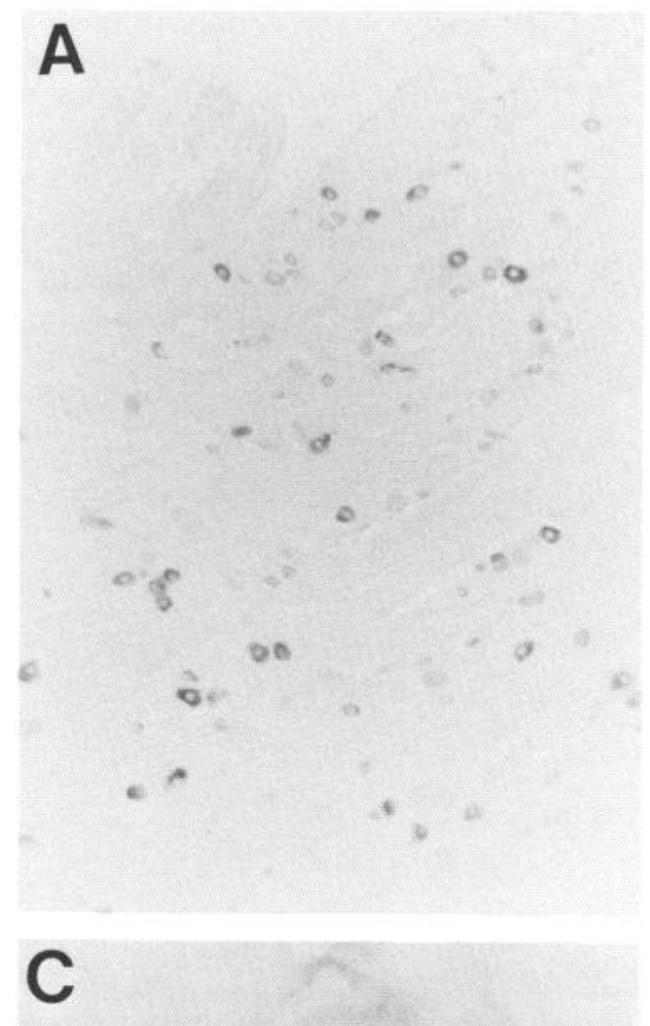

Figure 3. Immunocytochemical localization of the $57 \mathrm{kDa}$ neuronal IF protein in control and axotomized DRG neurons. Histological sections of contralateral control L5 DRGs $(A, C)$ and axotomized DRGs $14 \mathrm{~d}$ after sciatic nerve crush $(B, D)$ stained using a polyclonal antibody to the $57 \mathrm{kDa}$ protein. Scale bars: $100 \mu \mathrm{m}(A, B) ; 10 \mu \mathrm{m}(C$, D).
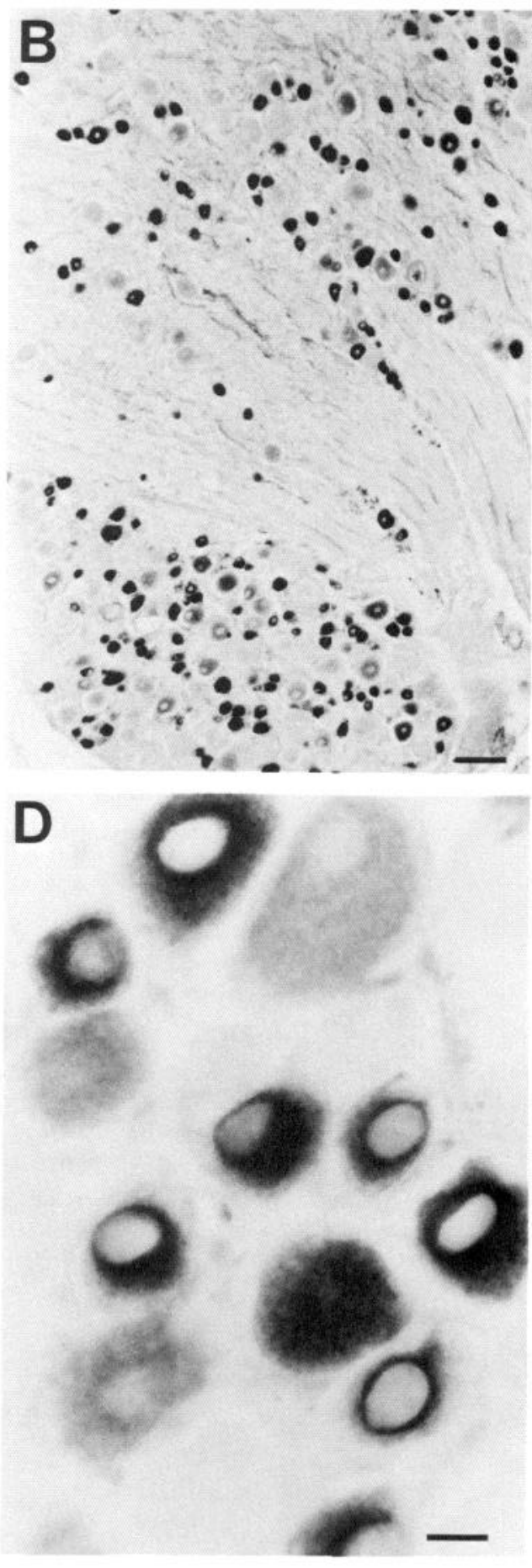

system express the type IV IF genes which code the NF triplet proteins (Shaw et al., 1981; Trojanowski et al., 1986). Generally, the level of NF expression is greatest in large-sized neurons that project large-diameter, myelinated axons (Lasek et al., 1983) and one of the well-studied functions of NFs in the nervous system is the maintenance of axonal caliber (Lasek et al., 1983; Hoffman et al., 1987). Only a subset of neurons in the adult rat, including small neurons of the DRG and sympathetic ganglia, some components of cranial nerves, ventral motor neurons, and neurons in a few nuclei and regions of the CNS, express the type III IF gene that encodes the $57 \mathrm{kDa}$ protein (Leonard et al.,
1988; Parysek and Goldman, 1988; Brody et al., 1989). With some exceptions, cells which express the $57 \mathrm{kDa}$ IF protein are generally small neurons with small caliber, mostly unmyelinated, axons. The differential patterns of normal expression of types III and IV IF genes in the normal adult animal imply that the 2 types of IF genes are regulated differentially in the nervous system.

Additional support for this idea comes from studies of injured neurons. The axotomy paradigm has been used quite extensively in the past few years to modulate the expression of cytoskeletal genes in neurons. The consensus from a number of different 

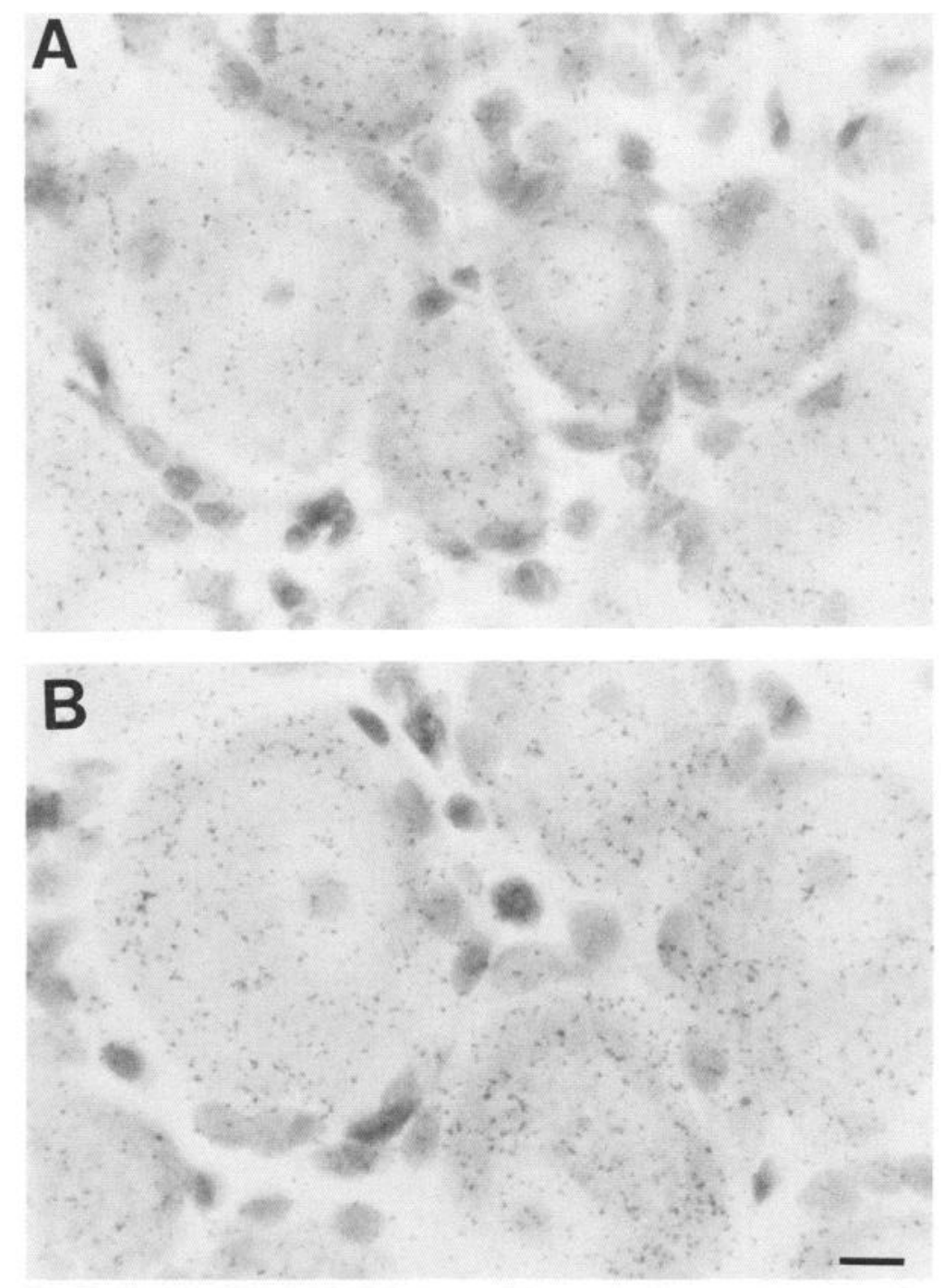

Figure 4. Localization of the $57 \mathrm{kDa}$ IF mRNA within L5 sensory neurons by in situ hybridization with a ${ }^{35} \mathrm{~S}$-labeled cDNA probe. The autoradiograms of $(A)$ normal control DRG neurons and $(B) 14 \mathrm{~d}$ postaxotomy DRG neurons were hybridized with the 57 $\mathrm{kDa}$ cDNA probe; slides were exposed for $8 \mathrm{~d}$. Scale bar, $10 \mu \mathrm{m}$. laboratories studying mRNA levels in the DRG indicates that the expression of Type IV IF (NF triplet) genes is down-regulated after axotomy (Hoffman et al., 1987; Wong and Oblinger, 1987; Goldstein et al., 1988; Hoffman and Cleveland, 1988; Oblinger et al., 1989). The synthesis and axonal transport of NF proteins is also known to be significantly reduced in axotomized neurons (Hoffman and Lasek, 1980; Oblinger and Lasek, 1985, 1988; Greenberg and Lasek, 1988; Oblinger et al., 1989). The findings of the present study provide the first evidence for up-regulation of an IF gene in regenerating neurons. In axotomized DRG neurons, the mRNA level for the $57 \mathrm{kDa}$ IF protein has been shown to increase during the same time span in which NF mRNAs levels are reduced. Additionally, the synthesis of the $57 \mathrm{kDa}$ IF protein has been shown to increase in axotomized DRG neurons that exhibit reduced levels of NF triplet protein synthesis. Finally, the levels of $57 \mathrm{kDa}$ IF protein in slow axonal transport have been shown to increase significantly in regenerating axonal sprouts of primed (previously axotomized) DRG neurons. Using this same paradigm for examining cytoskeletal protein transport in regrowing axons, we have recently demonstrated that significantly less NF triplet protein is transported in regrowing axons of primed DRG neurons (Oblinger et al.,
1989). Thus, based on a number of lines of evidence, it is clear that the $57 \mathrm{kDa}$ IF protein is regulated in a direction opposite that of the NF proteins after axotomy, supporting the hypothesis that Type III and IV IF genes are regulated differentially in the nervous system.

\section{Multiple levels of regulation of the $57 \mathrm{kDa}$ IF protein}

Several levels of regulation of the $57 \mathrm{kDa}$ IF protein have been implicated by the results of this study. First, in situ hybridization experiments indicate that the expression of $57 \mathrm{kDa}$ IF protein is regulated at the mRNA level. The significantly increased amounts of $57 \mathrm{kDa}$ IF mRNA observed in large-sized DRG neurons after axotomy could result either from a change in transcription rate or from a change in the level of mRNA degradation; these alternatives cannot be distinguished using the in situ methodology. It is of interest that the mRNA changes occurred only in the large-sized DRG neurons which normally have only low levels of $57 \mathrm{kDa}$ IF mRNA compared with small DRG neurons. Second, the results of pulse-labeling experiments indicated that the synthesis of $57 \mathrm{kDa}$ protein was increased in DRG cells after axotomy. Presumably, increased translation of the protein is a direct result of the increase in mRNA level. 


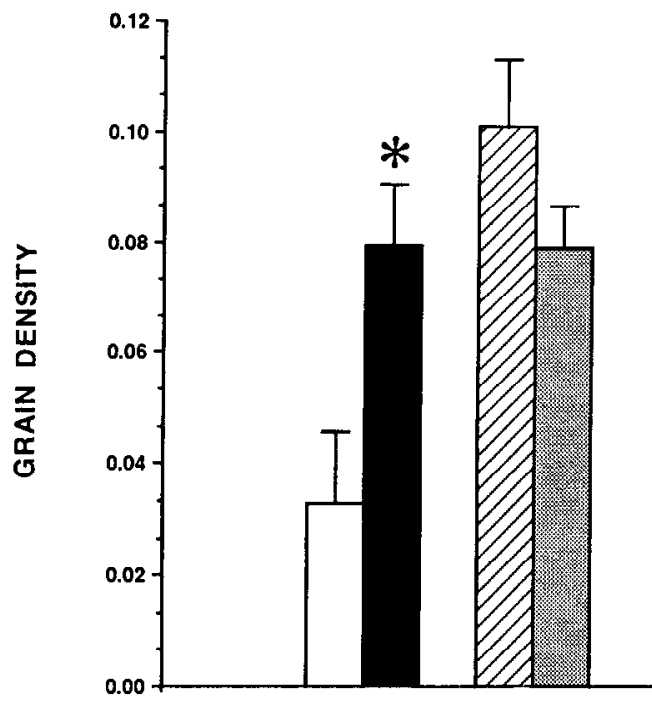

Figure 5. Quantitation of changes in the level of $57 \mathrm{kDa}$ IF mRNA in DRG neurons $14 \mathrm{~d}$ after peripheral axotomy. Mean grain densities (number of silver grains $/ \mu \mathrm{m}^{2}$ of cell area) were determined for normal large-sized DRG neurons (open bar), axotomized large-sized DRG neurons (solid bar), normal small-sized DRG neurons (striped bar), and axotomized small-sized DRG neurons (stippled bar). In all cases, only neurons in which a clearly defined nucleus and nucleolus were present were used for grain counting; 25-50 neurons in each size category per DRG were counted. The average grain densities and SEM are plotted; $n=6$ experimental and $n=4$ normal ganglia. The asterisk indicates statistical significance at $p<0.05$.

Additional levels of control of the expression of the $57 \mathrm{kDa}$ IF protein are also suggested by the results of this study. In this regard, a seeming discrepancy in the findings of immunocytochemical studies and in situ hybridization studies is of interest. After axotomy, immunocytochemical methods revealed that the level of $57 \mathrm{kDa}$ IF protein increased dramatically in both smalland large-sized DRG neurons. However, quantitative findings from in situ hybridization studies showed that the level of 57 kDa mRNA was significantly increased only in the large DRG neurons. The data indicate that the small DRG neurons exhibited a slight trend towards lower levels of mRNA after axotomy. Several possible explanations for these differences can be considered. For example, translational control mechanisms may be involved in the accumulation of $57 \mathrm{kDa}$ IF protein in the small DRG cells that did not exhibit a change in $57 \mathrm{kDa}$ IF mRNA level after axotomy. It is also possible that posttranslational mechanisms may be involved. For example, altered posttranslational processing may simply alter the immunodetectability of the $57 \mathrm{kDa}$ IF protein after axotomy. The $57 \mathrm{kDa}$ protein is known to be phosphorylated (Aletta et al., 1989), and it is possible that alterations in the level of phosphorylation might affect the presenting epitopes such that the antibody detectability of the protein is altered in a manner analogous to what has been reported for NF-H in the soma of axotomized neurons (Goldstein et al., 1987). Alternatively, differential posttranslational processing of the protein in axotomized and normal neurons might increase the stability of the protein and reduce its degradation in the cell body or affect its export from the soma into the axonal transport system. Any of these possibilities could potentially result in increased immunodetectable levels of the protein in small DRG cell bodies in the absence of a change in message level.
Finally, axonal transport is another possible level for control of the $57 \mathrm{kDa}$ IF protein. Results of the present study show that the $57 \mathrm{kDa}$ IF protein is a major labeled component of slow axonal transport in regenerating axonal sprouts, reaching a level approaching that of the NF proteins. While the transport of this protein has not yet been studied specifically in intact axons, examination of published data on slow axonally transported proteins in normal adult DRG axons revcals the $57 \mathrm{kDa}$ IF protein to be a very minor labeled species compared with the NF proteins (Oblinger, 1987; Oblinger et al., 1987). Little is known about the local mechanisms that regulate the movement of cytoskeletal proteins from large parent axons into the finecaliber regenerating axonal sprouts at an injury site. However, recent transport experiments have suggested that certain proteins may be selectively recruited into regenerating axons (McQuarrie and Lasek, 1988). Our present results would suggest that the $57 \mathrm{kDa}$ IF protein is one protein that is selectively recruited into axonal sprouts from parent axons.

\section{The role of IF proteins in axonal growth}

Intermediate filaments undoubtedly have important functions in axons, but for the most part many of these functions remain speculative. However, for the NFs, one well-characterized function is the regulation of axonal caliber (Lasek et al., 1983; Hoffman et al., 1987; Oblinger et al., 1989). During development, an increase in axonal diameter is a late event in the axonal growth process that, along with myelination, forms the maturation stage of axonal development. In developing axons, a relationship between increases in the number of NFs and increases in axonal diameter has long been established (Friede and $\mathrm{Sa}-$ morajski, 1970). While NF proteins have been detected in neurons during early embryonic stages (Bignami et al., 1982; Cochard and Paulin, 1984; Carden et al., 1987), it is clear that major increases in NF expression on both the protein level (Shaw and Weber, 1982; Willard and Simon, 1983; Pachter and Liem, 1984) and the mRNA level (Julien et al., 1986) occur only during later postnatal development. Thus, while the Type IV IF gene products may have additional important functions during development, it appears that one major role of NFs is in the maturational stage of axon growth.

In contrast to the NFs, the expression of vimentin, a type III IF gene product, appears to be a very early event in neuronal development. For example, replicating neuroepithelial cells contain vimentin but not NF proteins (Tapscott et al., 1981; Bignami et al., 1982; Bennett, 1987). During subsequent development when neuroblasts are formed and neurite growth ensues, vimentin is no longer expresscd (Bignami et al., 1982; Cochard and Paulin, 1984; Bennett, 1987). It is not yet clear whether 57 $\mathrm{kDa}$ expression precedes or follows the expression of vimentin (or NFs) during early neuronal development. However, recent studies have indicated that $57 \mathrm{kDa}$ expression begins quite early in development since the mRNA for the protein is detectable in E10 rat embryos (Parysek et al., 1988). To progress in our understanding of the role of type III IFs in neuronal development and axonal growth, future studies will need to define the details of expression of the $57 \mathrm{kDa}$ IF protein relative to vimentin and other IFs in developing neurons.

Regeneration studies have also provided some clues about the role of IFs in axonal growth. For the NFs, the consensus appears to be unanimous that high levels of NF expression are not desirable during active axonal regeneration. In various types of neurons examined to date, NF expression is down-regulated 
A

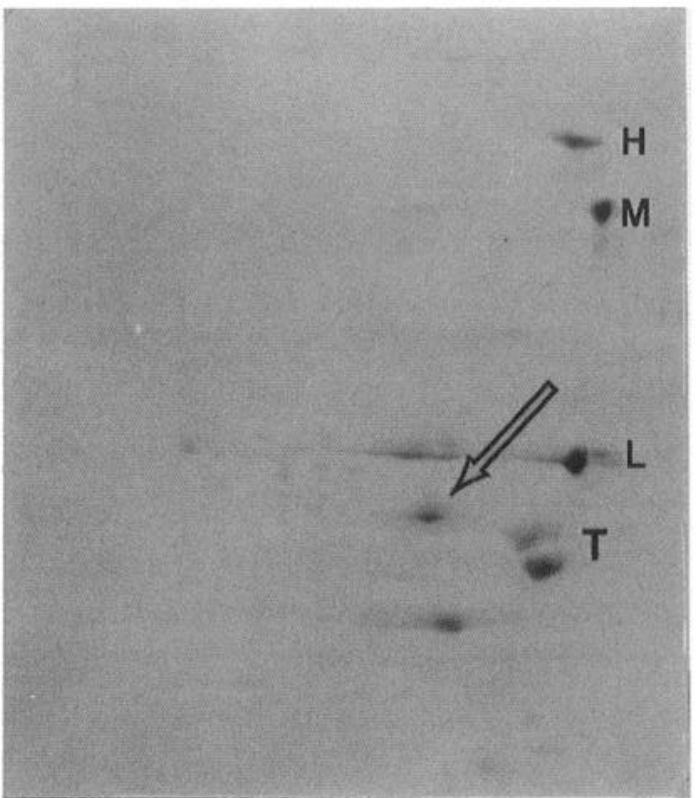

B

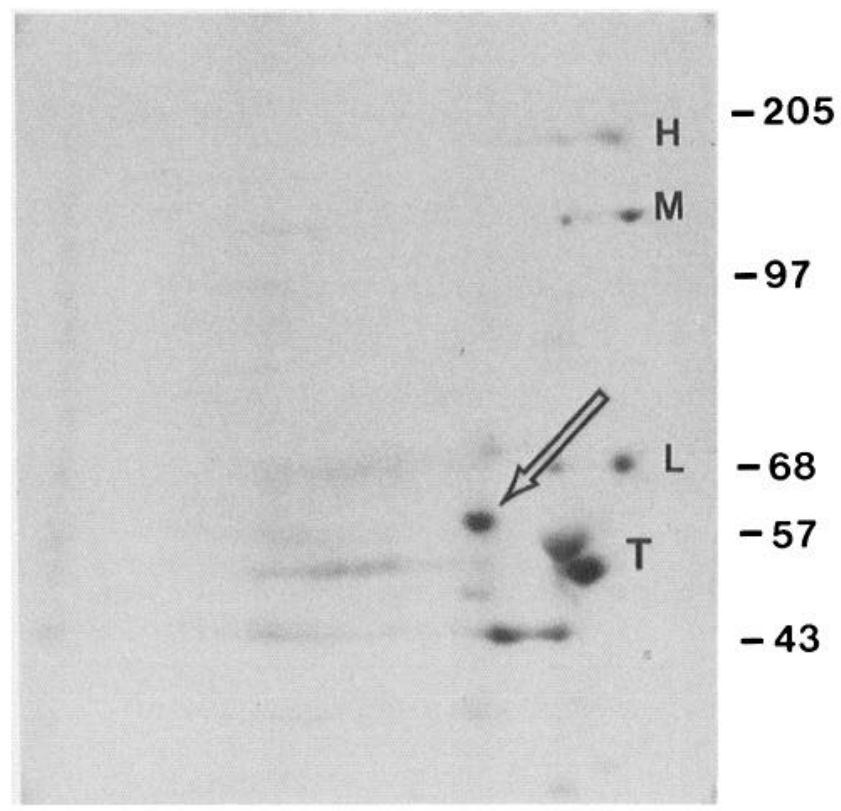

Figure 6. Axonal sprouts of primed DRG neurons convey more labeled $57 \mathrm{kDa}$ IF protein by slow axonal transport than those of unprimed DRG neurons. Fluorographs of $2 \mathrm{D}$ gel-separated proteins present in regenerating axonal sprouts $7 \mathrm{~d}$ after microinjecting L5 DRGs with ${ }^{35} \mathrm{~S}$-methionine and crushing the peripheral L5 nerve $2-4 \mathrm{~mm}$ from the ganglion (test crush) are shown. $A$, Unprimed DRG system. $B$, Primed DRG system; a conditioning lesion of the distal sciatic nerve was made 2 weeks prior to the labeling/test crush procedure. In both conditions, the samples used for the gels were homogenates of $10 \mathrm{~mm}$ segments of nerve located just distal to the test crush sites. The $57 \mathrm{kDa}$ protein is indicated by the arrows; $T$ marks the position of the $\alpha$ - and $\beta$-tubulins; $L, M$, and $H$ mark the position of the NF triplet proteins. Molecular-weight standards are indicated on the far-right side of gel panel in kilodaltons.

\section{A}

B
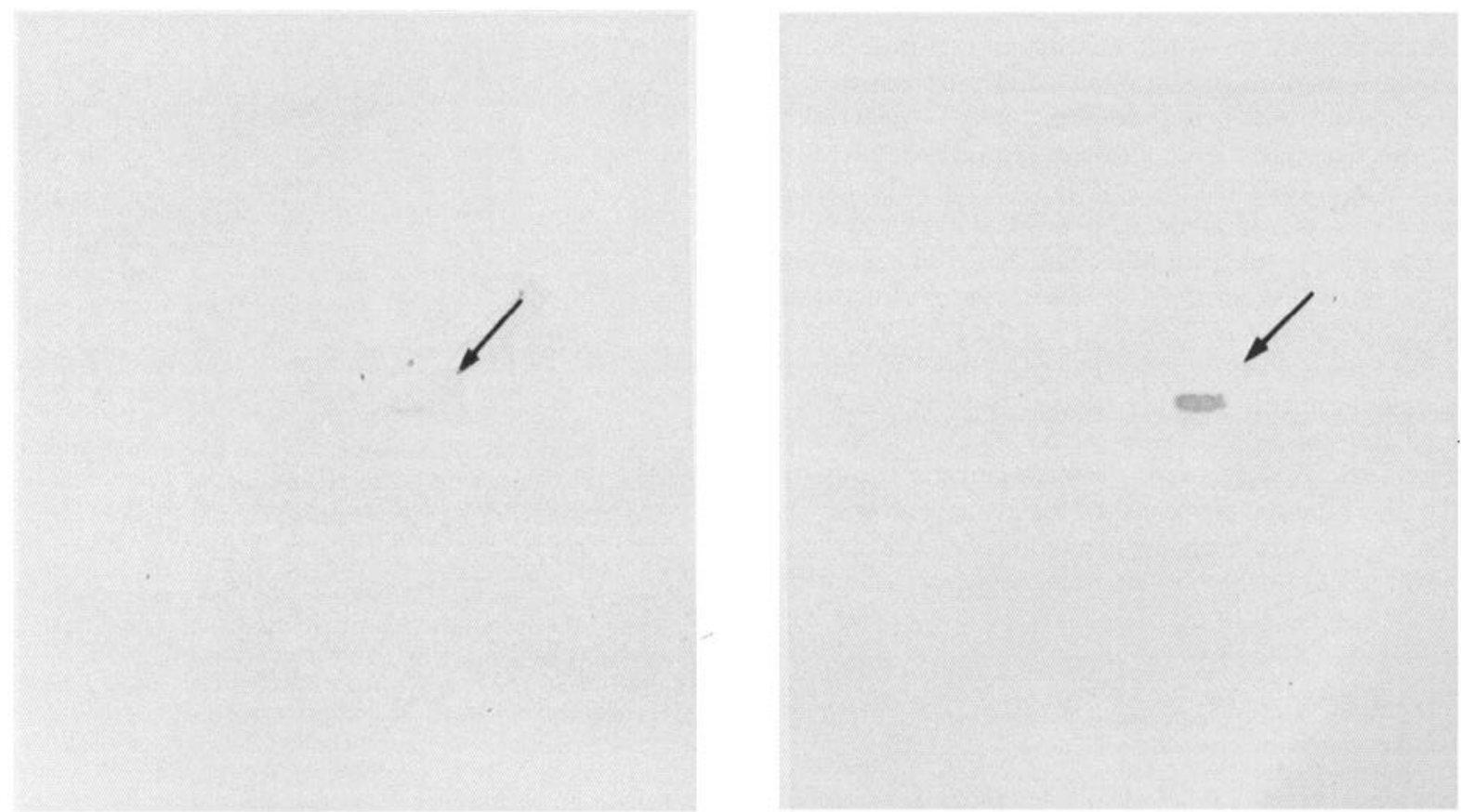

Figure 7. 2D gel-immunoblots of regenerating axons from unprimed and primed DRG neurons using a polyclonal antibody to the $57 \mathrm{kDa}$ IF protein. $A$, Unprimed DRG system. $B$, Primed DRG system. Equal amounts of total protein of homogenates of $10 \mathrm{~mm}$ segments of nerve located just distal to the test crush site were used for gels. Note the increase in the amount of the $57 \mathrm{kDa}$ protein (arrows) relative to total protein in the regenerating axons of primed DRG neurons. 
after axotomy, when axonal regrowth is occurring, suggesting that large numbers of NFs may actually hinder the active axonal elongation process (Hoffman and Lasek, 1980; Oblinger and Lasek, 1985, 1988; Hoffman et al., 1987; Wong and Oblinger, 1987; Oblinger et al., 1989). Support for this idea is provided by a recent study which demonstrated an increased axonal regeneration rate in DRG neurons that were axotomized during a time in which NF gene expression was reduced (after priming or conditioning lesions) (Oblinger et al., 1989). Accompanying NF down-regulation in axotomized $D R G$ is a reduction in the caliber of both parent axons (Hoffman et al., 1987) and regenerating axonal sprouts (Oblinger et al., 1989). A return to normal (or perhaps even increased) levels of NF gene expression results during the late stage of axonal regeneration, when axonal maturation occurs (Goldstein ct al., 1988; Hoffman and Cleveland, 1988).

Our current findings of up-regulation of the $57 \mathrm{kDa}$ IF protein in axotomized DRG neurons support the idea that this protein has an important function during active axonal elongation. In the $\mathrm{DRG}$, it is of particular interest that the major increase in $57 \mathrm{kDa}$ IF protein expression occurs in the large neurons of the DRG (which do not normally express significant levels of the protein) during regeneration. In preliminary studies using immunocytochemistry, large DRG neurons in E15 rat embryos were found to contain significant amounts of $57 \mathrm{kDa}$ IF protein; during subsequent development, the levels of $57 \mathrm{kDa}$ protein in the large neurons down-regulate to a very low level that is maintained in the adult (L. Parysek and C. A. Ley, unpublished observations). The up-regulation of $57 \mathrm{kDa}$ IF protein expression in the large DRG cells during axonal regeneration in the adult may be a recapitulation of the early developmental stages when active axonal elongation occurs.

Finally, axonal transport studies suggest that the $57 \mathrm{kDa}$ IF protein has an important function in regenerating axons. The results of the present study indicate that the $57 \mathrm{kDa}$ IF protein is a relatively abundant species in the cytoskeletal component of transport in regenerating axonal sprouts. In contrast, examination of published profiles of proteins slowly transported in normal axons or in intact parent axon regions of regenerating sensory neurons (Oblinger, 1987; Oblinger et al., 1987; Oblinger and Lasek, 1988) reveals the $57 \mathrm{kDa}$ IF protein to be a very minor labeled species compared with the major axonal cytoskeletal proteins: NF triplet, tubulins, and actin. This suggests that the $57 \mathrm{kDa}$ IF protein may be selectively recruited into newly regenerating sprouts. Whether or not the $57 \mathrm{kDa}$ IF protein is present in the same or different IFs as the NF proteins remains to be determined in future studies. However, in either event, altered amounts of $57 \mathrm{kDa}$ IF relative to the NF proteins in the cytoskeleton of regenerating axonal sprouts compared with normal may alter the properties of the axonal cytoskeleton in some manner. The significant up-regulation of $57 \mathrm{kDa}$ expression that is observed in the present study suggests that such a change may be beneficial to the axonal regrowth process.

\section{References}

Aletta, J. M., R. Angeletti, R. K. H. Liem, C. Purcell, M. L. Shelanski, and L. A. Greene (1988) Relationship between the nerve growth factor-regulated clone 73 gene product and the 58-kilodalton neuronal intermediate filament protein (Peripherin). J. Neurochem. 51: 13171320.

Aletta, J. M., M. L. Shelanski, and L. A. Greene (1989) Phosphorylation of the peripherin $58-\mathrm{kDa}$ neuronal intermediate filament pro- tein-regulation by nerve growth factor and other agents. J. Biol. Chem. 264: 4619-4627.

Bennett, G. S. (1987) Changes in intermediate filament composition during neurogenesis. Curr. Top. Dev. Biol. 21: 151-183.

Bignami, A., T. Raju, and D. Dahl (1982) Localization of vimentin, and nonspecific intermediate filament protein, in embryonal glia and in early differentiating neurons. Dev. Biol. 91: 286-295.

Brody, B. A., C. A. Ley, and L. M. Parysek (1989) Selective distribution of the $57 \mathrm{kDa}$ neural intermediate filament protein in the rat CNS. J. Neurosci. 9: 2391-2401.

Carden, M. J., J. Q. Trojanowski, W. W. Schlaepfer, and V. M.-Y. Lee (1987) Two-stage expression of neurofilament polypeptides during rat neurogenesis with early establishment of adult phosphorylation patterns. J. Neurosci. 7: 3489-3504.

Cochard, P., and D. Paulin (1984) Initial expression of neurofilaments and vimentin in the central and peripheral nervous system of the mouse embryo in vivo. J. Neurosci. 4: 2080-2094.

Friede, R. L., and T. Samorajski (1970) Axon caliber related to neurofilaments and microtubules in sciatic nerve fibers of rat and mice. Anat. Rec. 167: 379-388.

Goldstein, M. E., H. S. Cooper, J. Bruce, M. J. Carden, V. M.-Y. Lee, and W.W. Schlaepfer (1987) Phosphorylation of neurofilament proteins and chromatolysis following transection of rat sciatic nerve. $J$. Neurosci. 7: 1586-1594.

Goldstein, M. E., S. R. Weiss, R. A. Lazzarini, P. S. Shneidman, J. F. Lees, and W. W. Schlaepfer (1988) mRNA levels of all three neurofilament proteins decline following nerve transection. Mol. Brain Res. 3: 287-292.

Greenberg, S. E., and R. J. Lasek (1988) Neurofilament protein synthesis in DRG neurons decreases more after peripheral axotomy than after central axotomy. J. Neurosci. 8: 1739-1746.

Hoffman, P. N., and D. W. Cleveland (1988) Neurofilament and tubulin expression recapitulates the developmental program during axonal regeneration: Induction of a specific $\beta$-tubulin isotype. Proc. Natl. Acad. Sci. USA 5: 4530-4533.

Hoffman, P. N., and R. J. Lasek (1980) Axonal transport of the cytoskeleton in regenerating motor neurons: Constancy and change. Brain Res. 202: 317-333.

Hoffman, P. N., D. W. Cleveland, J. W. Griffin, P. W. Landes, N. J. Cowan, D. L. Price (1987) Neurofilament gene expression: A major determinant of axonal caliber. Proc. Natl. Acad. Sci. USA 84: 34723476.

Julien, J.-P., D. Meyer, D. Flavell, J. Hurst, and F. Grosveld (1986) Cloning and developmental expression of the murine neurofilament gene family. Mol. Brain Res. 1: 243-250.

Lasek, R. J., M. M. Oblinger, and P. F. Drake (1983) The molecular biology of neuronal geometry: The expression of neurofilament genes influences axonal diameter. Cold Spring Harbor Symp. Quant. Biol. 48: 731-744.

Leonard, D. G. B., J. D. Gorham, P. Cole, L. A. Greene, and E. B. Ziff (1988) A nerve growth factor-regulated messenger RNA encodes a new intermediate filament protein. J. Cell Biol. 106: 181-193.

McQuarrie, I. G., and R. J. Lasek (1988) Transport of cytoskeletal elements from parent axons into regenerating daughter axons. J. Neurosci. 9: 436-446.

Oblinger, M. M. (1987) Characterization of posttranslational processing of the mammalian high molecular weight neurofilament protein in vivo. J. Neurosci. 7: 2510-2521.

Oblinger, M. M., and R. J. Lasek (1985) Selective regulations of two axonal cytoskeletal networks in dorsal root ganglion cells. In Neurobiology: Molecular Biological Approaches to Understanding Neuronal Function and Development, P. O'Lague, ed., pp. 135-143, Liss, New York.

Oblinger, M. M., and R. J. Lasek (1988) Axotomy induced alterations in the synthesis and transport of neurofilaments and microtubules in dorsal root ganglion cells. J. Neurosci. $8: 1747-1758$.

Oblinger, M. M., S. T. Brady, I. G. McQuarrie, and R. J. Lasek (1987) Cytotypic differences in the protein composition of the axonally transported cytoskeleton in mammalian neurons. J. Neurosci. 7: 453-462.

Oblinger, M. M., R. A. Szumlas, J. Wong, and F. J. Liuzzi (1989) Changes in cytoskeletal gene expression affect the composition of regenerating axonal sprouts elaborated by dorsal root ganglion neurons in vivo. J. Neurosci. 9: 2645-2653.

Pachter, J. S., and R. K. H. Liem (1984) The differential appearance of neurofilament triplet polypeptides in the developing rat optic nerve. Dev. Biol. 103: 200-210. 
Parysek, L. M., and R. D. Goldman (1987) Characterization of intermediate filaments in PC12 cells. J. Neurosci. 7: 781-791.

Parysek, L. M., and R. D. Goldman (1988) Distribution of a novel $57 \mathrm{kDa}$ intermediate filament (IF) protein in the nervous system. J. Neurosci. 8: 555-563.

Parysek, L. M., R. L. Chishold, C. A. Ley, and R. D. Goldman (1988) A Type III intermediate filament gene is expressed in mature neurons. Neuron 1: 395-401.

Portier, M.-M., P. Brachet, B. Croizat, and F. Gros (1984a) Regulation of peripherin in mouse neuroblastoma and rat PC12 pheochromocytoma cell lines. Dev. Neurosci. 6: 215-226.

Portier, M.-M., B. deNechaud, and F. Gros (1984b) Peripherin, a new member of the intermediate filament protein family. Dev. Neurosci. 6: 335-344.

Shaw, G., and K. Weber (1982) Differential expression of neurofilament triplet proteins in brain development. Nature 298: 277-279.

Shaw, G., M. Osborn, and K. Weber (1981) An immunofluorescence microscopical study of the neurofilament triplet proteins, vimentin and glial fibrillary acidic protein within the adult rat brain. Eur. J. Cell Biol. 26: 68-82.
Steinert, P. M., and D. R. Roop (1988) Molecular and cellular biology of intermediate filaments. Annu. Rev. Biochem. 57: 593-625.

Tapscott, S. J., G. S. Bennett, Y. Toyama, F. Kleinbart, and H. Holtzer (1981) Intermediate filament proteins in the developing chick spinal cord. Dev. Biol. 86: 40-54.

Thompson, M. A., and E. B. Ziff (1989) Structure of the gene encoding peripherin, an NGF-regulated neuronal-specific type III intermcdiatc filament protein. Neuron 2: 1043-1053.

Trojanowski, J. Q., N. Walkenstein, and V. M.-Y. Lee (1986) Expression of neurofilament subunits in neurons of the central and peripheral nervous system: An immunohistochemical study with monoclonal antibodies. J. Neurosci. 6: 650-660.

Willard, M. B., and C. Simon (1983) Modulations of neurofilament axonal transport during the development of rabbit retinal ganglion cells. Cell 35: 551-559.

Wong, J., and M. M. Oblinger (1987) Changes in neurofilament gene expression occur after axotomy of dorsal root ganglion neurons. An in situ hybridization study. Metab. Brain Dis. 2: 291-303. 